\author{
تأثير مديريت كاربرد كود سبز و تيمارهاى كود دهى آن بر خصوصيات \\ فيزيكى - شيميايى و حاصلخيزى خاك \\ محدثه شمس الدين سعيد '، احمد قنبرى ‘، محمود رمرودى ؟ و امين خضرى؟

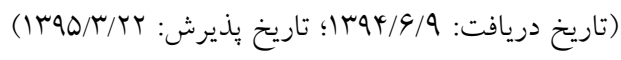

جكيده

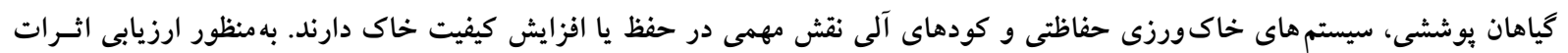

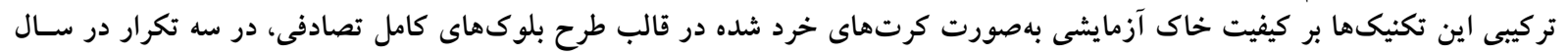

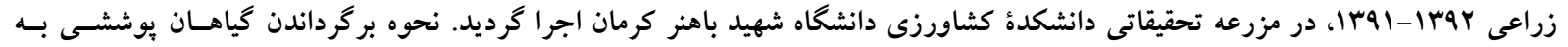

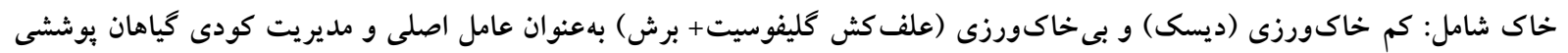

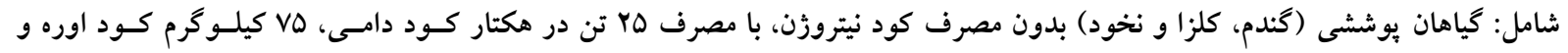

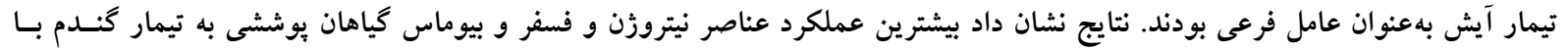

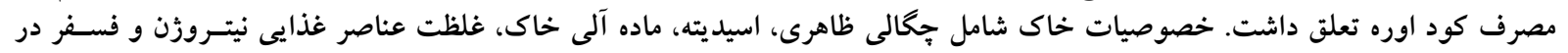

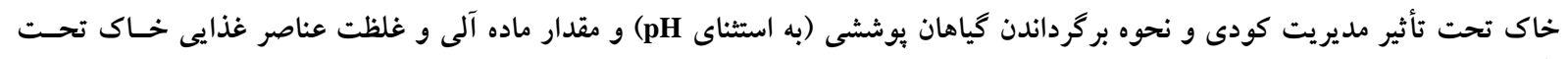

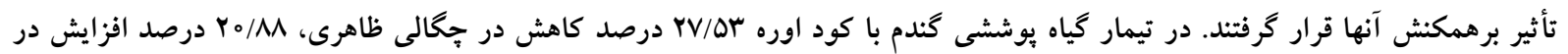

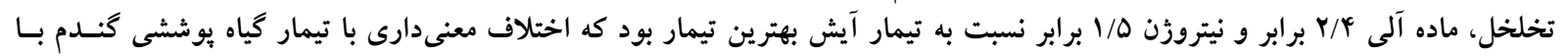

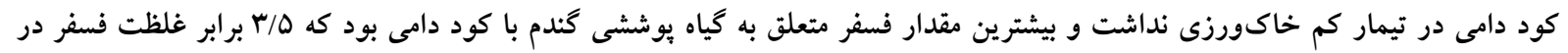

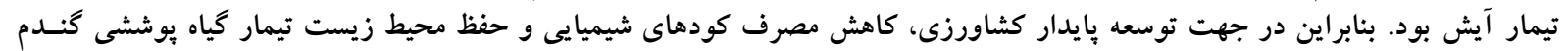

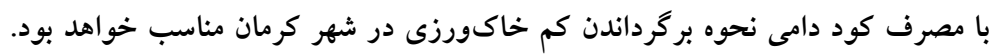

وازههاى كليدى: گياهان يوششى، نحوه برگرداندن، مديريت كود، كيفيت خاى

ا. كروه توليدات گياهى، دانشكده كشاورزى بردسير، دانشكاه شهيد باهنر كرمان

r. گروه زراعت، دانشكده كشاورزى، دانشخاه زابل

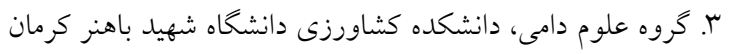

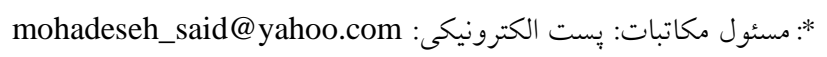




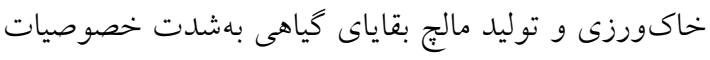

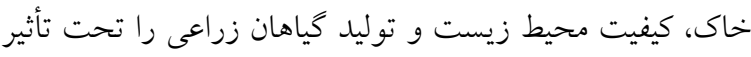

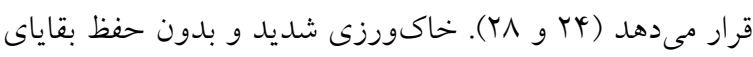

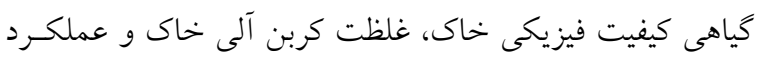

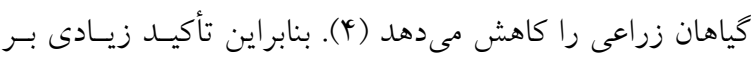

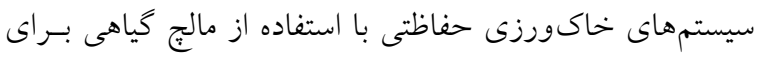
كاهش خطر فرسايش، بهبود كيفيت خاك از طريق افزايش مـاده

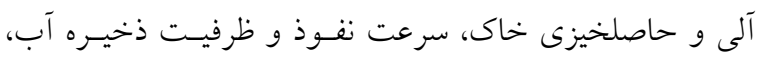

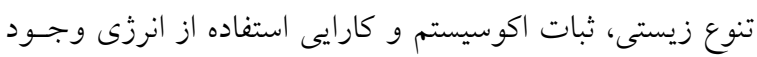

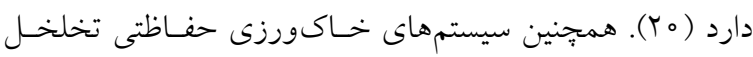

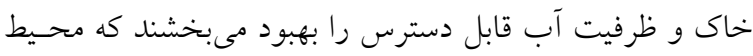

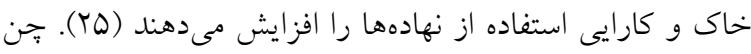

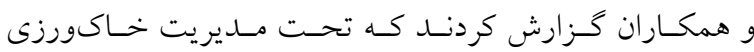

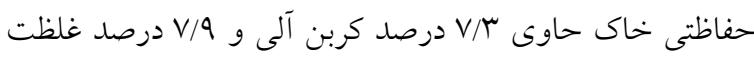

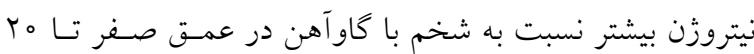
سانتى مترى بود (V)

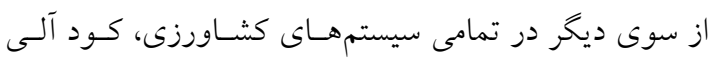

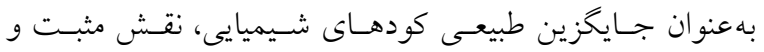
غيرقابل انكارى در مديريت بايدار خاك و درنهايت بايدارى كل

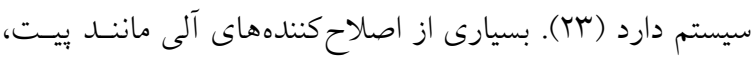

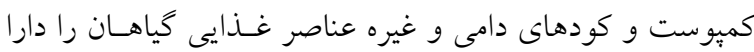

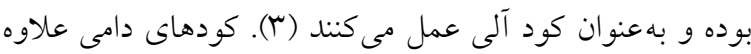

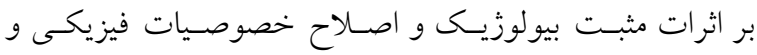
شيميايى خاك بهعلت اين كه عناصر غذايى آنها به آهستخى آزاد مى شود و در اختيار كياه قرار مى گيرد، در محيطزيست آلـودگى لهى كمترى ايجاد مى كنند (Y9). غازان شاهى اظهار نمود كه مى توان در زمينهاى زراعى با مصرف كودهاى دامى حسدود با درصــ نيتروزن، وY درصد فسفر و QV درصد يُ بتاسيم را تأمين كرد (Y).

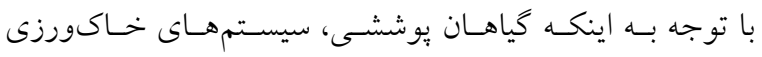

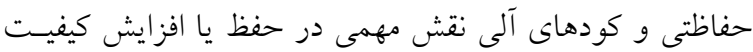

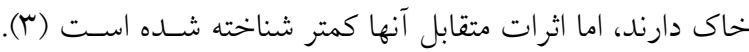

همزمــان بــا افـزايش رشـــ جمعيـت در كشــورهاى در حـال بيشرفت، كاهش زمينهاى حاصلخيز و افزايش نياز بــراى غــذا،

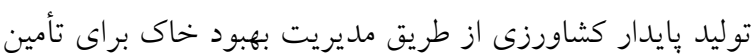

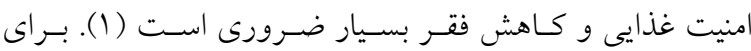
حفاظت خـاك و محسيط زيست بسـيارى از كشـورها از قبيـل

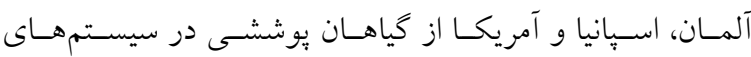

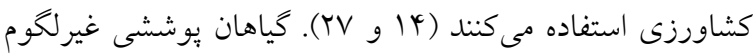

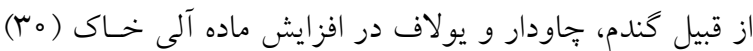

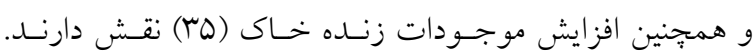

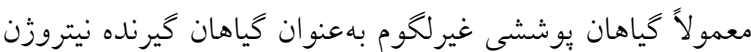

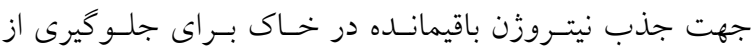

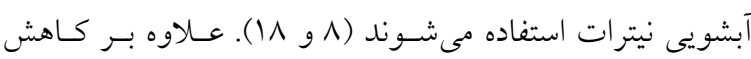
تلفات نيترات كاشت كياهان يوششى مز ايـاى متعـددى شـامل

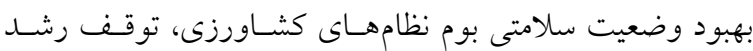

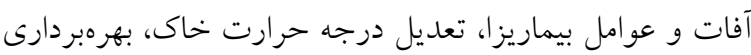
از اضافات كودها و كاهش رواناب كودها، كنترل علفهاى هرز

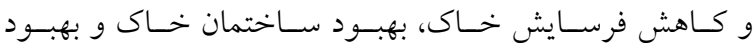
حاصلخيزى خاك دارند (4)). كياهان يوششى لكومينوز بهدليـل

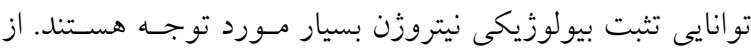

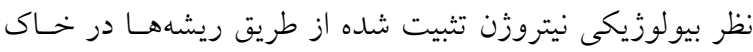

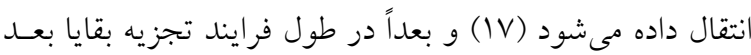

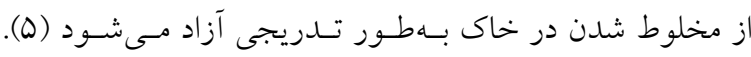

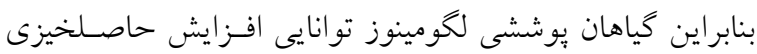

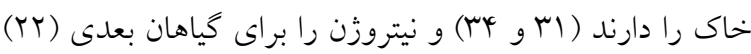
فراهم مى كنند. عوامل محيطى از قبيل بارندكى، درجه حسرارت،

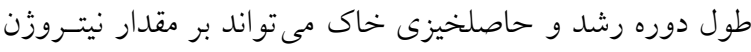

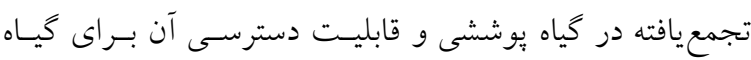

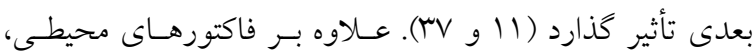
تصـميمات مـــيريتى از جملـه عمليـات خــاكورزى و زمــان بركرداندن كياه يوششى به خاك، بر قابليت دسترسى نيتروزن و

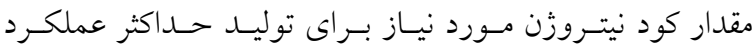




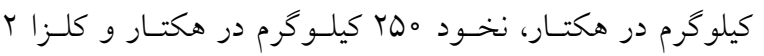

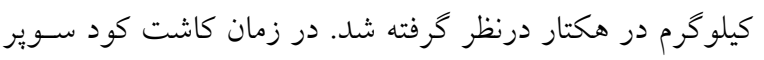

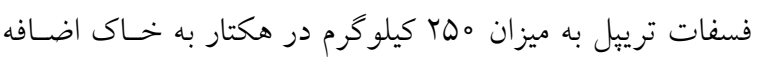
شد. اواخر دهه اول ارديبهشت مـاه ابتــا از تيمارهـاى كياهـان

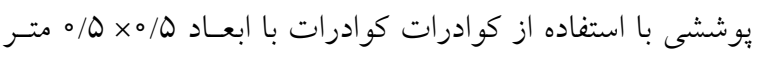

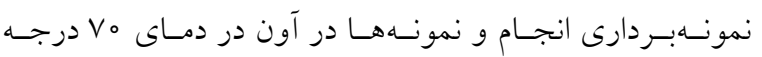

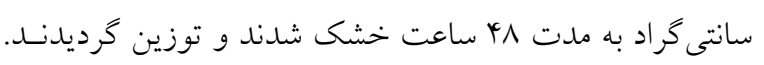

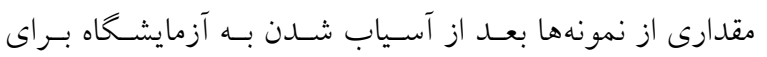
اندازهكيرى ميزان نيتروزن و فسفر انتقـال داده شـــند. در تيمـار

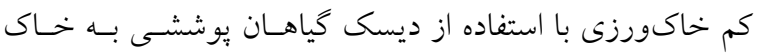

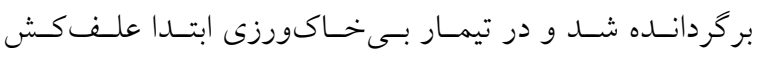

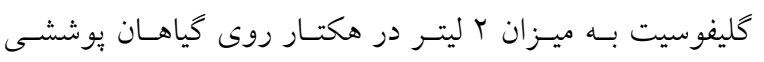

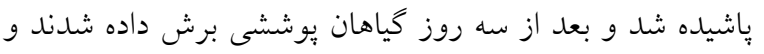

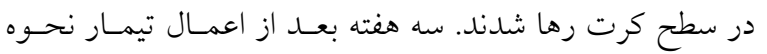

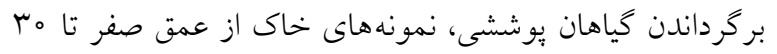
سامتىمترى خاى با استفاده از اوكر برداشت شد و و به به آزمايشكاه

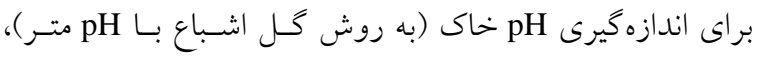

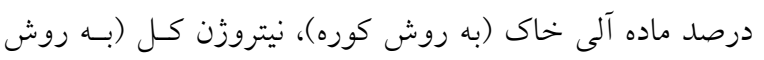

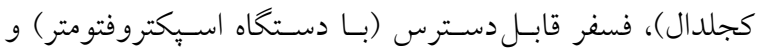

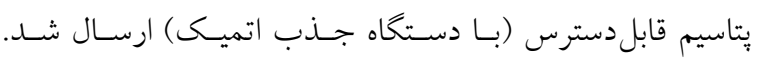

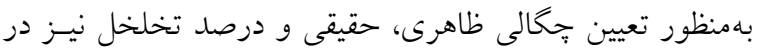
همان نقاط نمونه بردارى از خاك بهوسيله سـيلندر انجـام شـد.

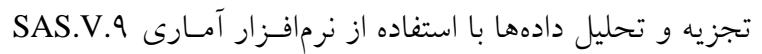

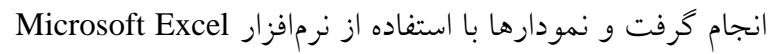
رسم شدند.

\section{نتايج و بحث}

بيوماس كياهان بوششى: تيمارهـاى مختلـف مـــيريت كـودى،

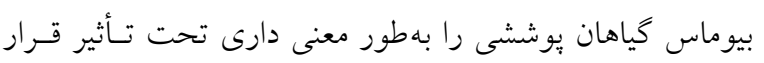

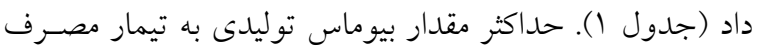

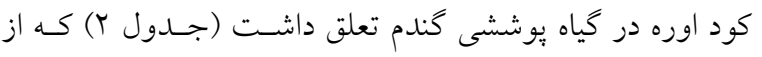
اين نظر اختلاف معنى دارى با تيمار مصرف كود دامى در كيـاه

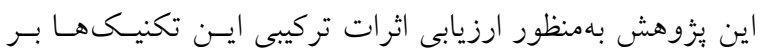

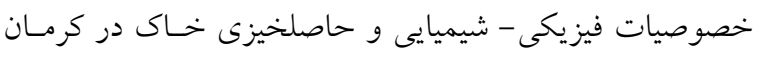

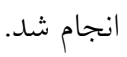

\section{مواد و روشها}

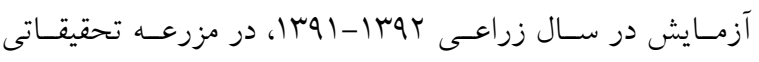

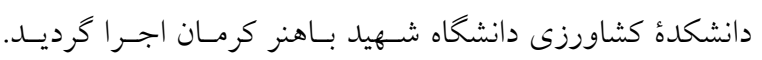

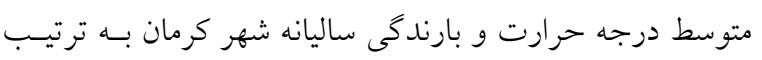

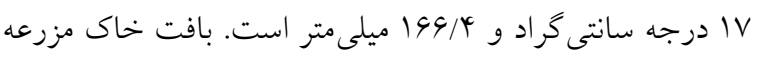

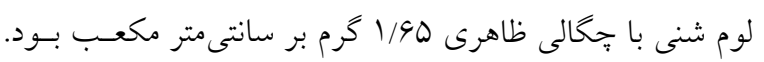

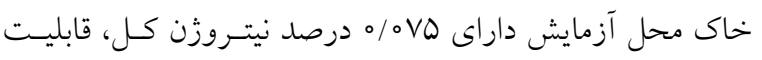

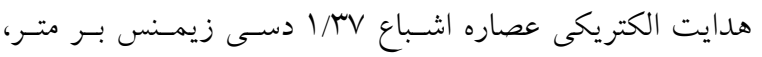

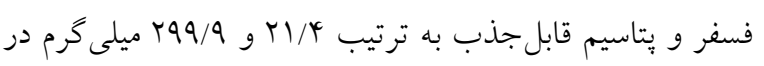

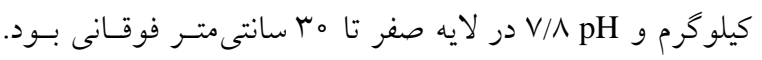

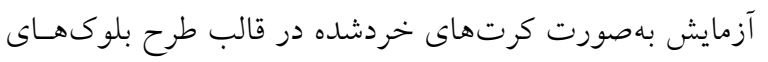

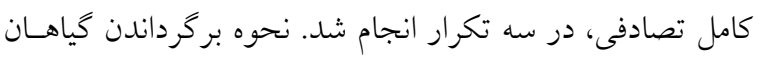

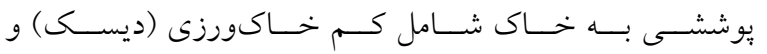
بى خاكورزى بهعنوان عامل اصـلى و مـــيريت كـودى كياهـان

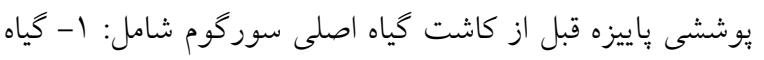
يوششى كندم بدون مصرف كود نيتروزن و كود دامى، ب- كئاه يوششى كلزا بدون مصرف كود نيتروزن و كود دامى، بـ بـ كيـاه يوششى نخود بدون مصرف كود نيتروزن و كود دامى، بأ- كيـاه

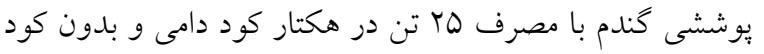

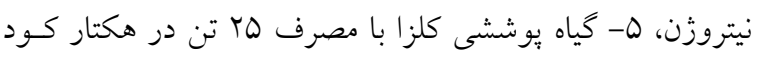

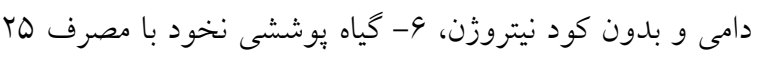

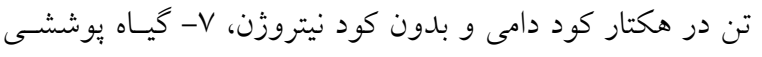

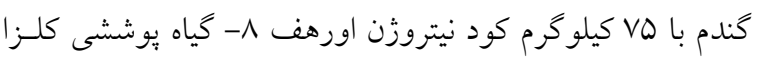

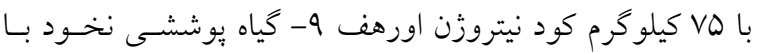

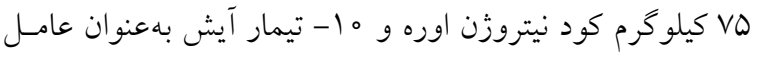

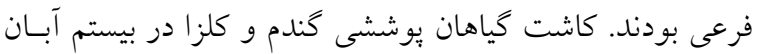

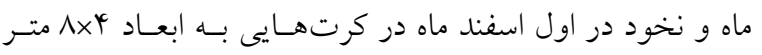
بهورت 


\begin{tabular}{|c|c|c|c|c|}
\hline \multicolumn{3}{|c|}{ ميانخين مربعات } & \multirow{2}{*}{ درجه آزادى } & \multirow{2}{*}{ منابع تغييرات } \\
\hline عملكرد فسفر & عملكرد نيتروزن & 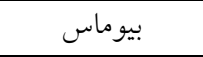 & & \\
\hline$r 9 / 00$ & $911 / 49$ & 190Trq/9T & r & بلوى \\
\hline$Y \circ Q /\left.Y\right|^{* *}$ & $V V Q \Delta / \Gamma_{0}^{* *}$ & GNKEYI9/90 & $\wedge$ & مديريت كود گياه يوششى \\
\hline MT/OT & $9 \Delta V / \wedge \Delta$ & $\| 119 \mid \mathrm{F} / \mathrm{M}$ & 19 & خطا \\
\hline
\end{tabular}

جدول r. مقايسه ميانگين وزن خشك گياهان يوششى، درصد نيتروزن، عملكرد نيتروزن، درصد فسفر و عملكرد فسفر

\begin{tabular}{|c|c|c|c|}
\hline عملكرد فسفر (Kg.ha-1) & عملكرد نيتروزن (Kg.ha-1) & بيوماس (Kg.ha-1) & \\
\hline$|r / 4|^{b-d}$ & $9 \circ / 10^{b-d}$ & $r \mu V \circ / V \circ b c$ & كندم \\
\hline$T r / V^{a b}$ & $1 \circ \Delta / 9 \circ b c$ & GMYY/Ooab & كندم و كود دامى \\
\hline$r \Lambda / V \Lambda^{\mathrm{a}}$ & $r \circ V / D^{\circ} a$ & $\varphi \circ \mu_{\circ} / \varphi_{\circ} a$ & كندم و اوره \\
\hline N/N Y & $9 \mathrm{~V} / \mathrm{A}^{\circ} \mathrm{b}-\mathrm{d}$ & $191 \% / \mathrm{V} \circ \mathrm{c}$ & كلزا \\
\hline $\mid V / q 4 c b c$ & $9 \wedge / 9_{0} \mathrm{~b}-\mathrm{d}$ & MTIV/V。bc & كلزا و كود دامى \\
\hline $\mid r / Y V^{b-d}$ & $119 / \mathrm{V} \circ \mathrm{b}$ & $r V \wedge Q / Y_{0} b c$ & كلزا و اوره \\
\hline$Q / I V^{e}$ & $\mathrm{rq} / \mathrm{ood}^{\mathrm{d}}$ & $\mid Y V Y / \circ \circ C$ & نخود \\
\hline $4 / 90^{\mathrm{e}}$ & $\mathcal{F} / \mathcal{C}_{\circ} \mathrm{cd}$ & $14+\pi / 1 \circ \mathrm{C}$ & نخود و كود دامى \\
\hline G/A re & $\Lambda \circ / \mu_{\circ} b-d$ & Tytil/9obc & نخود و اوره \\
\hline
\end{tabular}

درصد و \&V/90 درصد كمتر بود، اما در مورد كياه بوششى كلزا

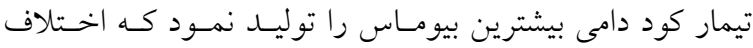
معنى دارى با تيمار كود اوره نداشت (جدول (1). گياهان خانواده براسيكاسه داراى توانايى زيادى در جذب مقـادير بـالاى فسـفر مىباشند (1) كه در حضور كود دامى بر طبق نتايج جـدول (Y)، درصد فسفر در بافت كياهى كلزا در تيمار مصسرف كـود دامسى بيشتر از تيمار مصرف كود اوره و عدم مصسرف كـود اوره بـود. بنابراين در اين تيمار توليد بيوماس كياهى بيشتر بود.

\section{عملكرد نيتروزن گياهان يوششى}

نتايج نشان داد عملكرد نيتروزن بهطور معنى دارى تحـت تـأثير تيمارهاى مختلف مديريت كودى قرار گرفت (جـدول ()) و در هر سه كياه يوششى بيشترين نيتروزن متعلق به تيمـار كـود اوره

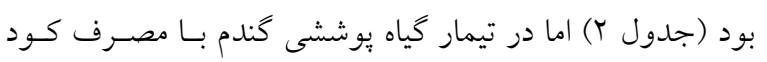

يوششى كنـدم نداشـت و كمتـرين بيومـاس توليـدى بـه كيـاه يوششى نخود در تيمار عدم استفاده از كود نيتروزن متعلسق بـود (جدول Y). در واقع در هر سه مـديريت كـودى گيـاه يوششىى كندم توانست بيشترين مقدار بيوماس را توليد نمايد، گيـاه كلـزا

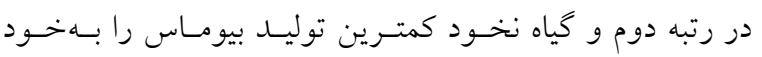
اختصـاص دادنــ كــه از يكسـو بـه خصو صـيات رشـدى ايسن كونهاى گياهى مرتبط مى شود و از سوى ديخر به مقاومت بـالا

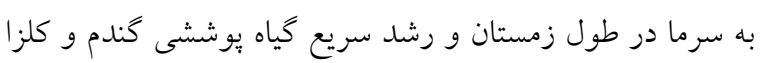

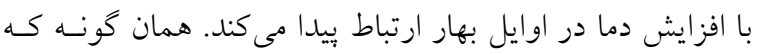

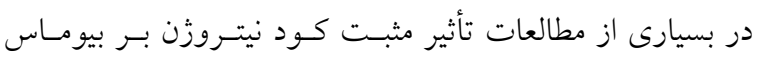

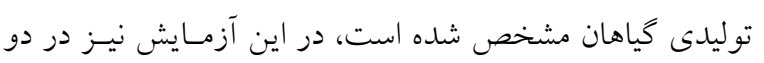
تيمار مصرف كود دامى و عدم استفاده از كود اوره ميزان توليـد بيوماس نسبت به تيمار مصرف كود اوره به ترتيب در گياه گندم

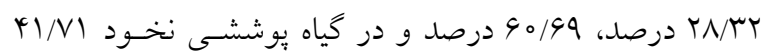


تأثير مديريت كاربرد كود سبز و تيمارهاى كود دهى آن بر خصوصيات فيزيكى ...

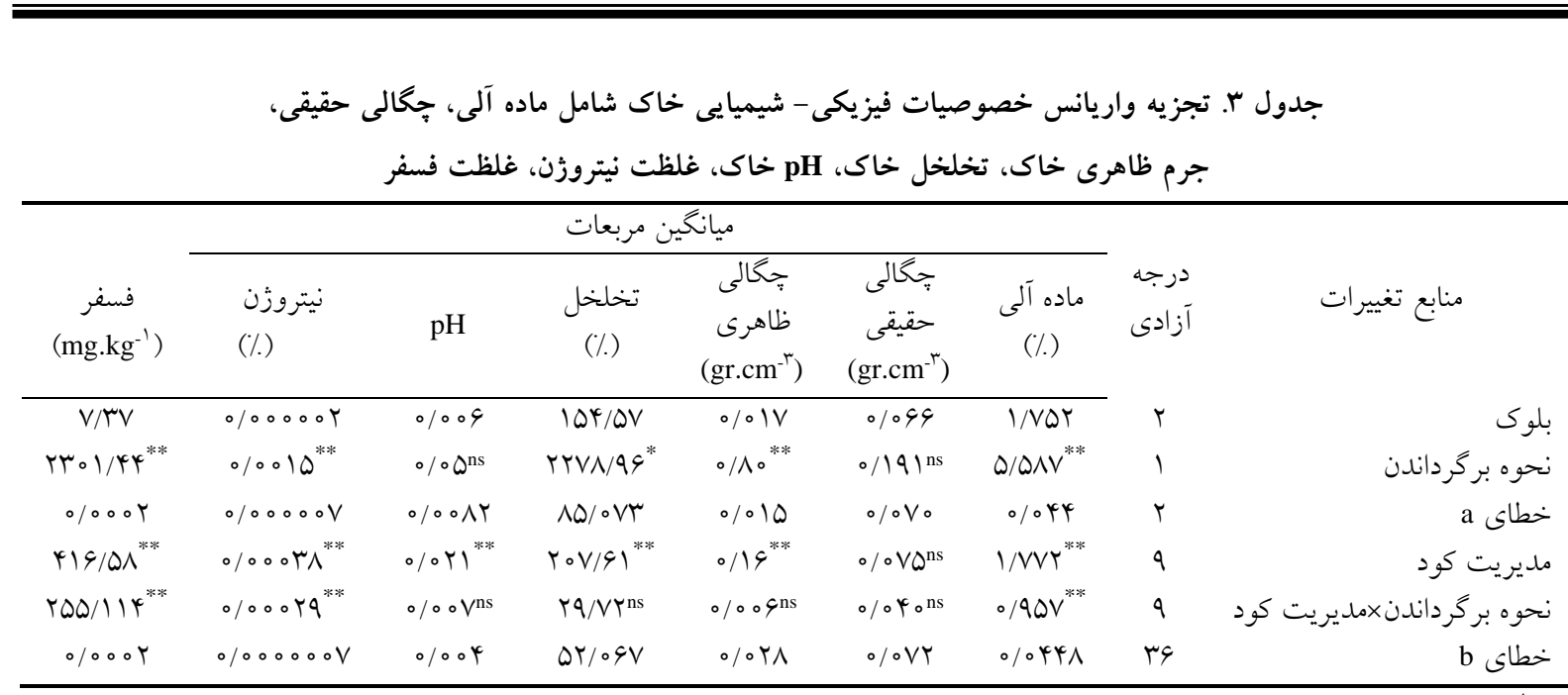

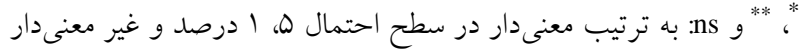

همبستخى مثبت و معنى دار (r=0/9V) بيوماس كياهى و عملكرد

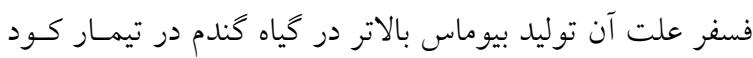
اوره است و كمترين عملكرد فسفر متعلق به گياه يوششى نخود بود (جدول Y). در گياه بوششى كلزا بيشترين عملكرد فسفر در تيمار مصرف كود دامى مشـاهده شـد كـه نسـبت بـه دو تيمـار مصرف كود اوره و عدم مصرف كود اوره بهترتيب 1/0 و سم/ T برابر بود. در صورت استفاده از كودهاى دامسى بـهـعلـت وجـود اسيدهاى آلى حلاليت فسفر در خاك افزايش مى يابد و درنتيجه

جذب آن توسط كياه نيز زياد مى شود (1).

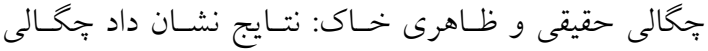
حقيقى خاى تحت تأثير عمليات مديريت برداشـت و مــديريت كود گياهان يوششى و برهمكنش آنها قرار نخرفت (جــدول س). غـازان شـاهى (r) بيـان نمــوده اسـت كــه جخـالى حقيقـى از خصوصيات ذرات خاك بوده و با عمليات زراعى تغيير نمى كند و ثابت مى ماند، اما جخَالى ظاهرى خاى كـه نشـاندهنده تـر اكم خاى است بهطور معنسى دارى در سـطح ا درصـد تحـت تـأثير تيمار خاكورزى مورد استفاده در تيمار نحوه برگرداندن گياهان

$$
\text { يوششى قرار گرفت. }
$$

به كونهاى كه جّالى ظاهرى خاك در تيمار كم خـاكورزى با درصد نسبت به تيمار بى خاكورزى كاهش يافـت (جــدول ץ)، كه علت آن مدفون شدن حجــم زيــادى از بقايـاى گياهـان
وره بيشترين عملكرد نيتروزن مشاهده شد و گياه يوششى كلـزا در رتبه دوم و گياه وششى نتخـود در رتبـهـ سـوم قـرار گرفتــــ

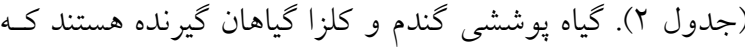
بهعلت توانايى جذب بالاى عناصر غذايى مىتوانند نقش مفيدى را براى اكوسيستمهاى زراعى و كاهش آلودگى خاك به عناصـر غذايى بازى كنند (1). ساير محققين نيز نشان دادند كه برخى از كونهاى كندميان و براسيكا در بهدام انداختن نيتروزن در يـاييز

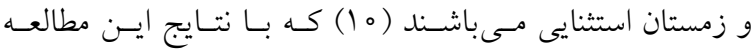
مطابقت دارد. عملكرد نيتـروزن در گيـاه يوششى گنسـدم در دو تيمار كود دامسى و بــون مصسرف كـود اوره نسـبت بـه تيمـار

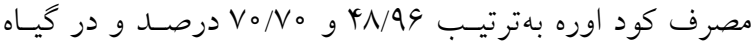

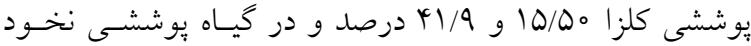

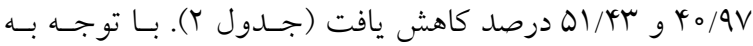

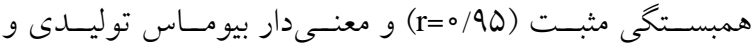
عملكرد نيتروزن، توليد بيوماس بالاتر در گندم نسبت به كلـزا و نخود باعث شده است كه عملكرد نيتروزن بيشترى داشته باشد. عملكرد فسفر كياهان يوششى: اخرجه بين جـــب نيتـروزن خاك و فسفر اثرات آنتاكونيستى وجود دارد و با افزايش ميـزان نيتروزن در خاك جذب فسفر كاهش مى يابـد (غـازان شـاهى، \& كندم با مصـرف كـود اوره بـود (جــدول r) كـهـ بـا توجـهـ بــه 
جدول ه. ضرايب همبستخى خصوصيات فيزيكى - شيميايى خاك

\begin{tabular}{|c|c|c|c|c|c|c|}
\hline فسفر خاك & نيتروزن خاك & تخلخل نهايى & ״جخالى ظاهرى & جِحالى حقيقى & ماده آلى خاك & \\
\hline & & & & & 1 & ماده آلى خاك \\
\hline & & & & 1 & $\circ / 0 \Delta Y$ & جشالى حقيقى \\
\hline & & & 1 & $\circ / 1 \wedge$ & $-0 / 99^{* *}$ & جֶ) ظلى ظاهرى \\
\hline & & 1 & $-\circ / V Q^{* *}$ & $0 / 00^{* *}$ & $0 / 90^{* *}$ & تخلخل نهايى \\
\hline & 1 & $0 / 44^{* *}$ & $-0 / 4 q^{* *}$ & $\% / 4$ & $0 / 9 Y^{* *}$ & نيتروزن خاك \\
\hline 1 & $\circ / \Delta \Delta^{* *}$ & $0 / 4 \mu^{* *}$ & $-0 /\left.4\right|^{* *}$ & $0 / 1 Y$ & $\circ / v^{* *}$ & فسفر خاى \\
\hline$-0 / 1 r$ & $-0 / T Q$ & $-O / K T$ & $0 / Y_{0}$ & $-0 / 0 \wedge$ & $-0 / 14$ & $\mathrm{pH}$ \\
\hline
\end{tabular}

تيمارهاى مصرف كود دامس در كنـدم، كلـزاو و نخسود اخـتلاف

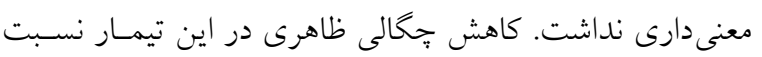

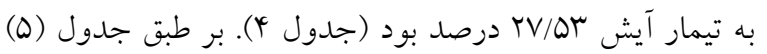

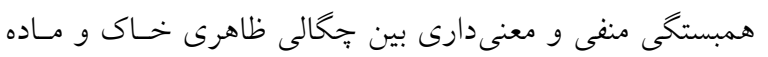
آلى خاى وجود داشت.

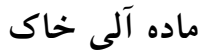

از تمامى ويزگى هاى خاك، ماده آلى خـاكى عـاملى اسـت كـه. انسان مى تواند بيشترين نقش را در تغييرات آن داشته باشد. ماده

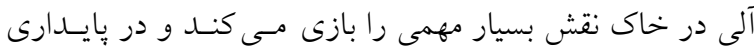

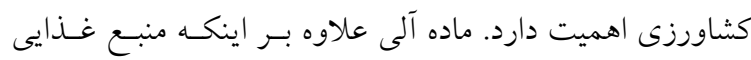

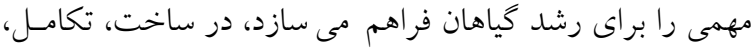

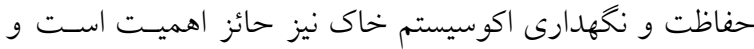
بهنوان جز مهم ساختمان خاك جهت افزايش نخهـدارى آب و عناصر غذايى بهعنوان منبع غذا براى ميكرواركانيسمهاى خـاك و فراهم كننده حفاظت مكانيكى سطح خاك مطرح اسـت. بستهـه به نوع عمليات زراعى مورد استفاده اين خصوصيات مس توانــ

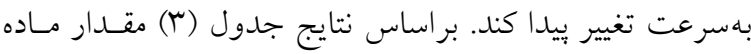

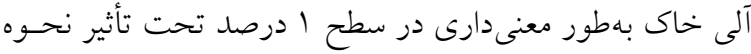

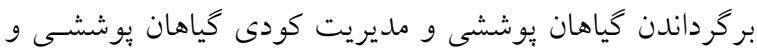
برهمكنش آنها قـرار كرفـت (P<0/01). مقايسـه ميـانخينهـاى

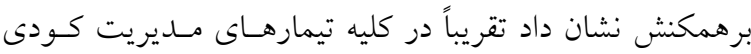

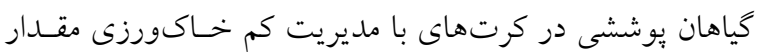

يوششى در خاك و كاهش فشردكى خاك اسـت. در واقـع هـر

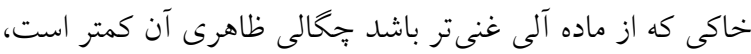

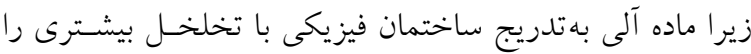

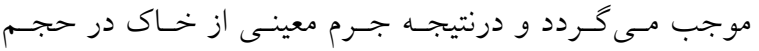
بيشترى تظاهر مىنمايد. كال و همكاران (10) بيشـترين تـراكم يوسته را در سيستم بـ خاكورزى نسبت به خاكورزى حــاقل

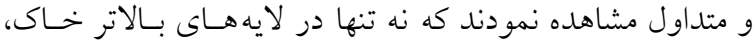

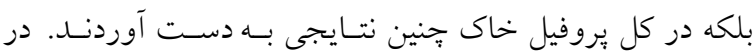
حاليكه دالال و همكاران (9) در خاك ورتى سول هيج تفـاوتى

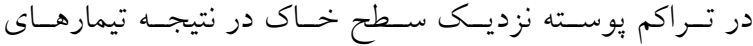

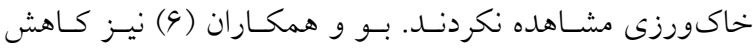

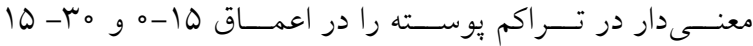

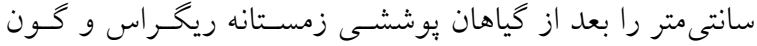
كزارش نمودند و علت آن را فعاليتهـاى فيزيكسى ريشهـهـاى قوى گياهان يوششى در خاك بيان نمودند. اما دنيش و همكاران

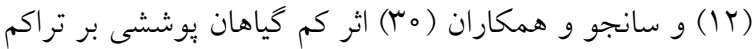
يوسته خاك را كزارش نمودند. نتـايج متفـاوت اثـر تيمـارهـاى خاكورزى بر خصوصيات خاك در آزمايشها كوناكون بهدليـل تفاوت در طول مدت اجراى آزمايش اسـت. همجنــين جخحـالى ظاهرى خاى تحت تأثير تيمارهاى مختلف مديريت كود كياهان يوششى تفــاوت معنسىدارى نشـان داد (جسـول ب). بيشـترين

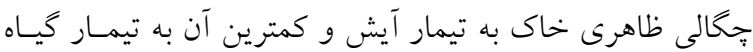
يوششى كُندم با مصرف كود اوره تعلق داشت كه از اين نظر بـا بـا 


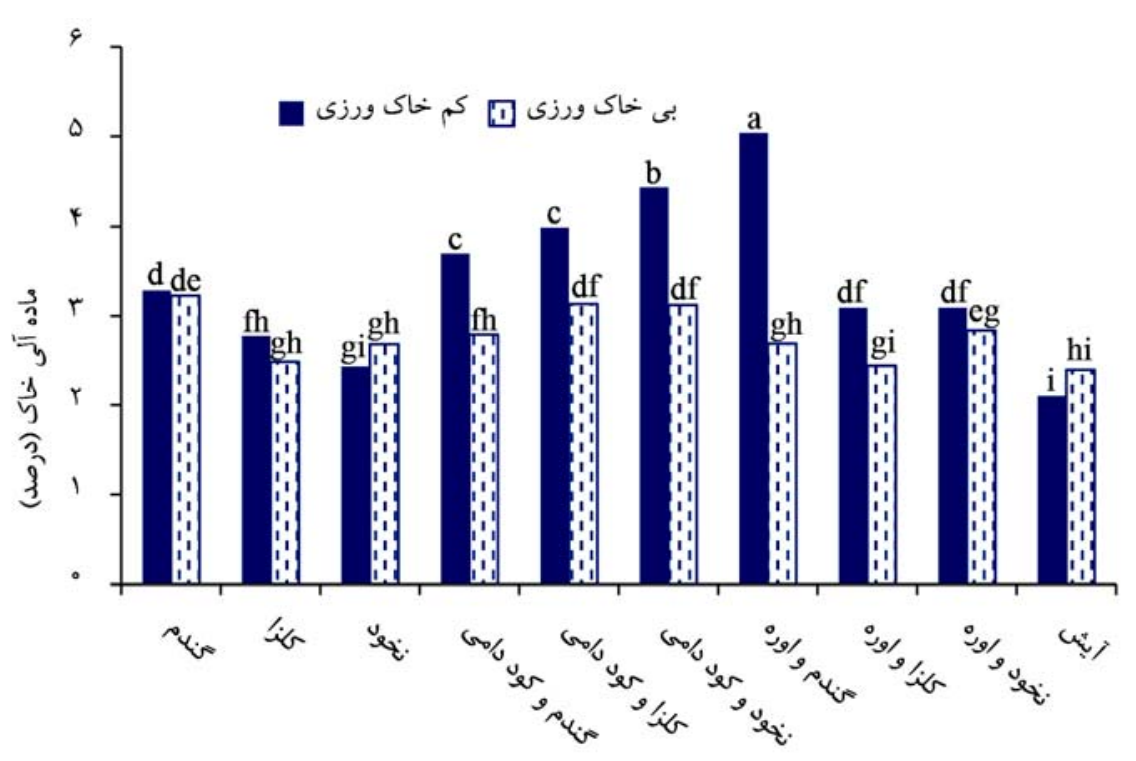

شكل ا. تأثير برهمكنش نحوه بركرداندن و مديريت كودى گياهان بوششى بر ميانخين ماده آلى خاك

متــداول افـزايش داد كـهـ آنهـــا مــاده آلـى بيشـتر در تيمسار

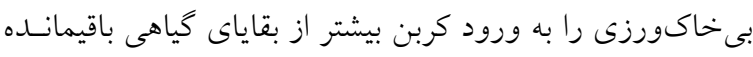

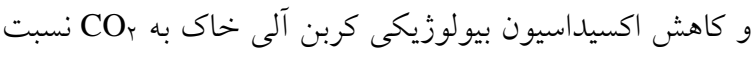

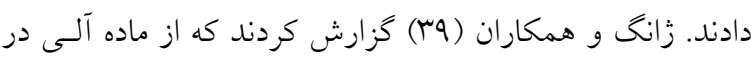

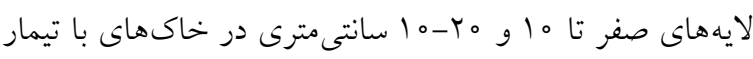

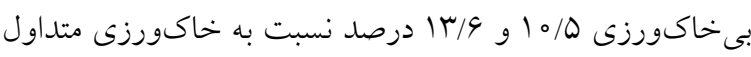
بيشتر بود. بهطور مشابهى هوانـح و همكـاران (19) نيـز نشـان

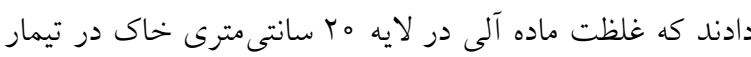
بى خاكورزى ^أ درصد مقايسه خاكورزى متداول بيشتر بود.

درصد تخلخل خاى عامل ديخرى كه در تعيين كيفيت خاك تأثير خـذار اسـت ميـزان

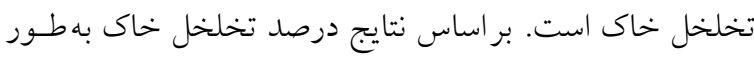
معنى دارى تحت تأثير نحوه بركرداندن و مديريت كودى كياهان

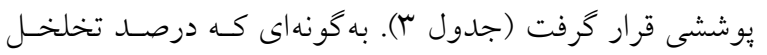

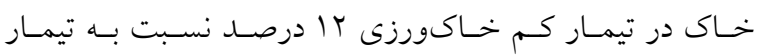

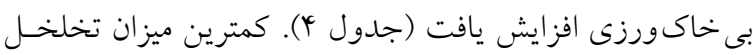

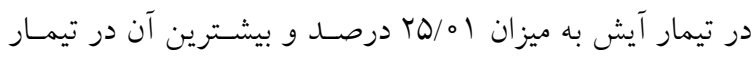

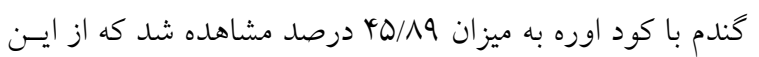

ماده آلى بيشترى نسبت به تيمار بسىخـاكورزى وجــود داشـت

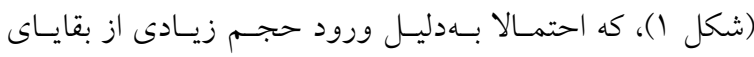

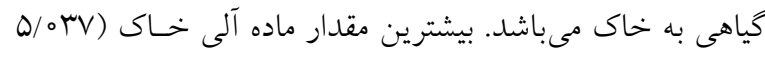

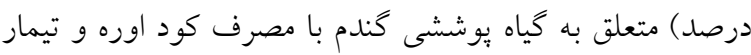

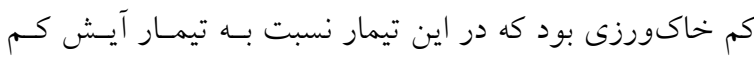

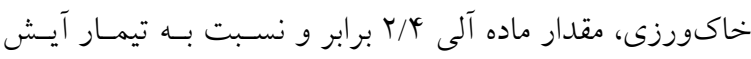

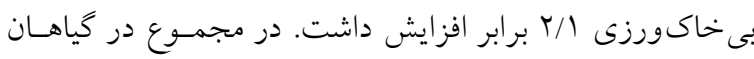

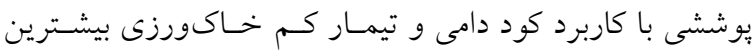

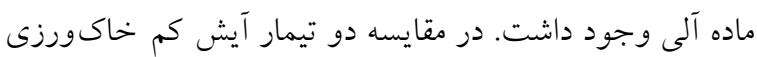

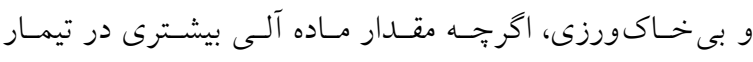

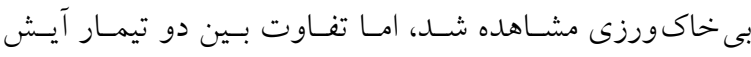

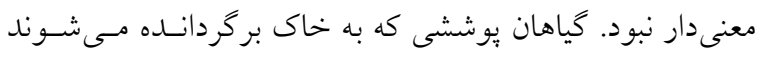

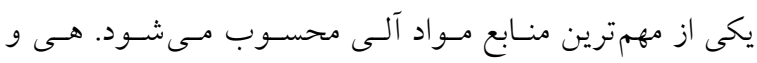

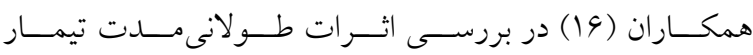

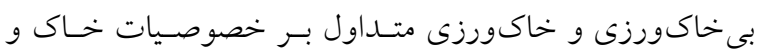
عملكرد گياهان در سيستم كشت مضاعف گُندم زمستانه- ذرت

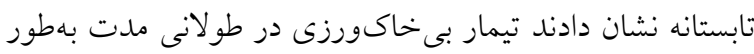

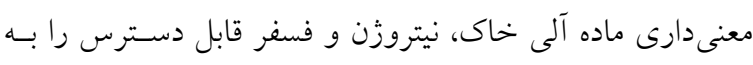

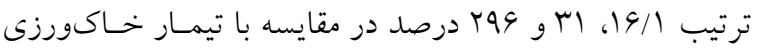




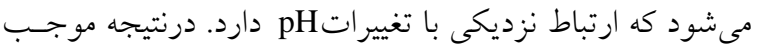

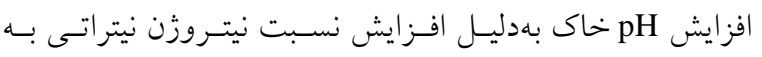

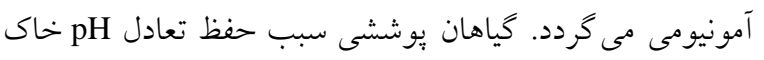

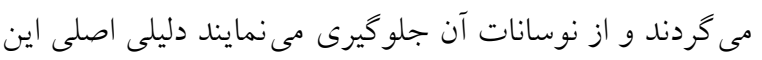

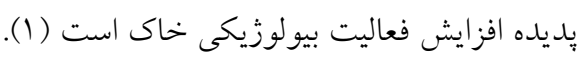

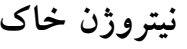

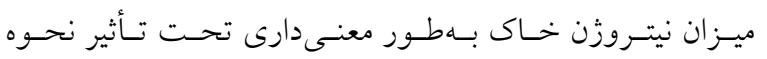

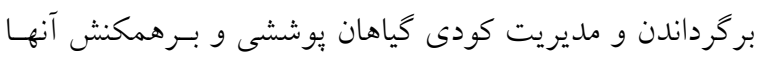

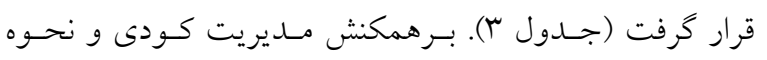

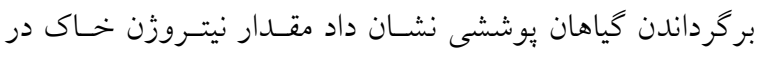

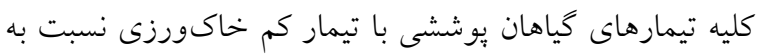

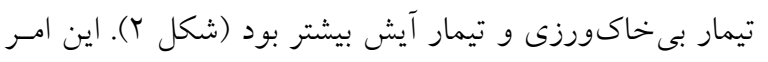

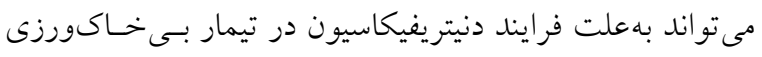

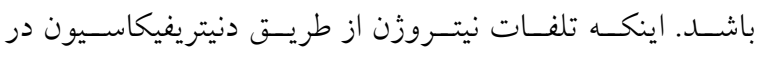

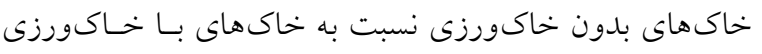

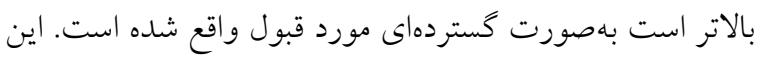

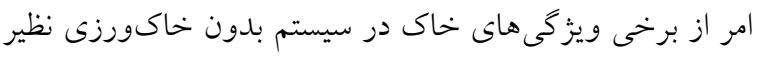

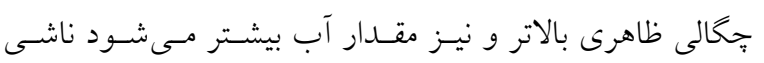
مى گردد. مطالعات آزمايشكاهى نشان داده است كه محل قراركيــى

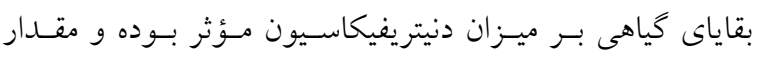

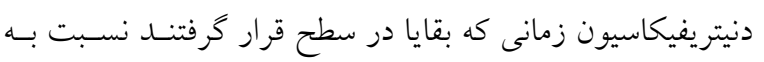

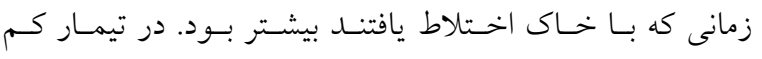

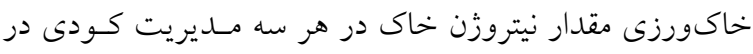

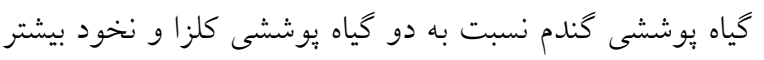

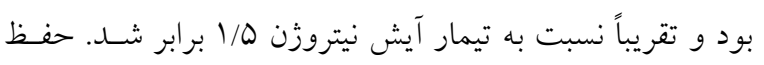

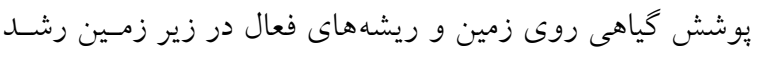

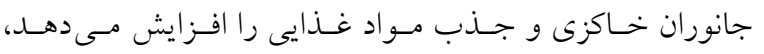
درنتيجه اين امر موجب كاهش آبشويى نيتروزن مى گرددو. گنــدم

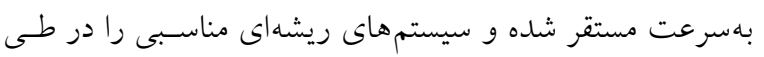

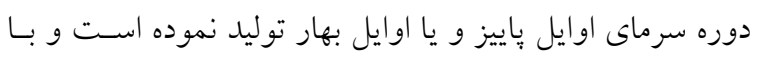

نظر اختلاف معنى دارى با تيمار كندم و كود دامسى نداشـت. در

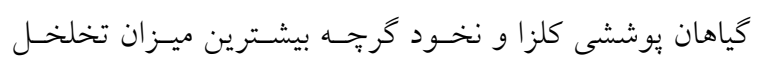

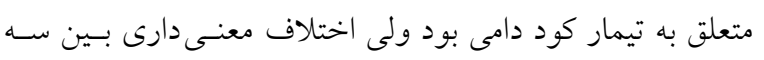
نوع مديريت كودى وجود نداشت. با توجه به همبستكى داده ها

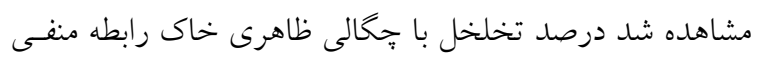

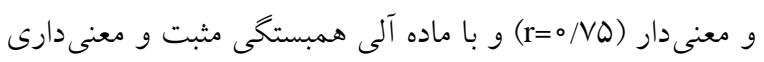

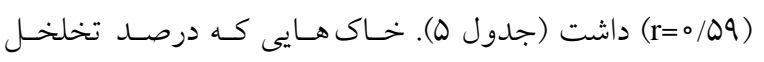

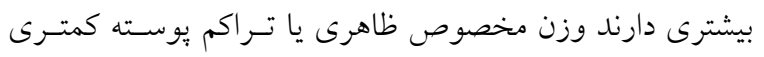

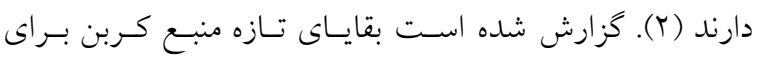

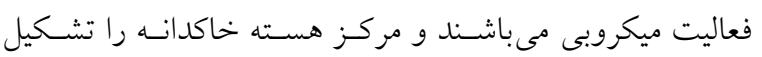

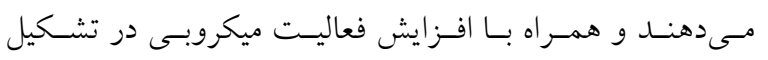

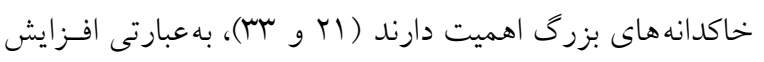

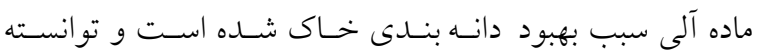

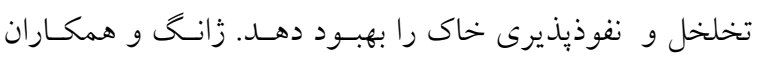

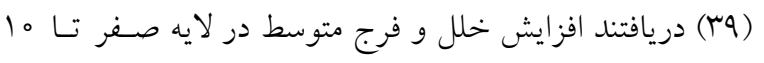

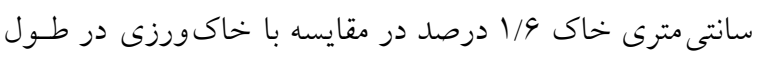
سه سال آزمايش افزايش يافت.

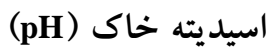
تغييرات pH خاك بر عواملى مانند دسترسى به عناصـر غـذايى،

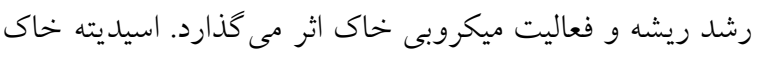

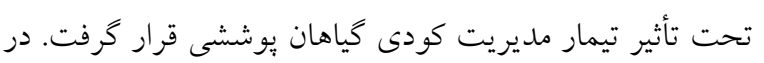

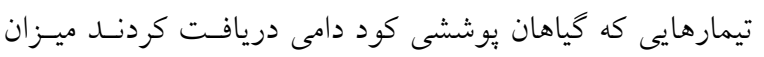

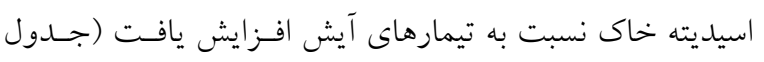

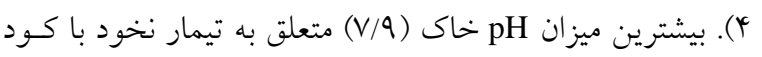

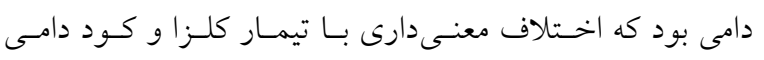

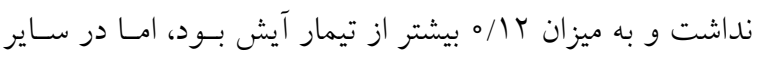

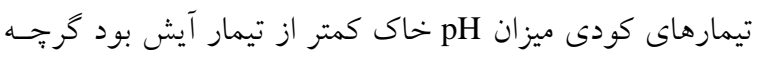

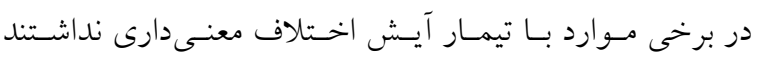

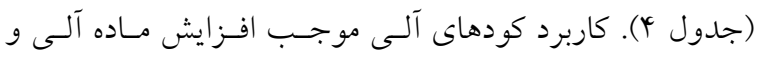

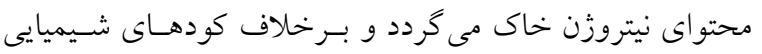

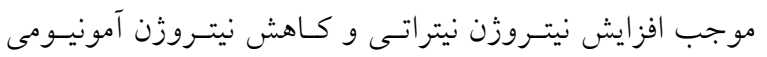




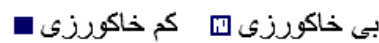

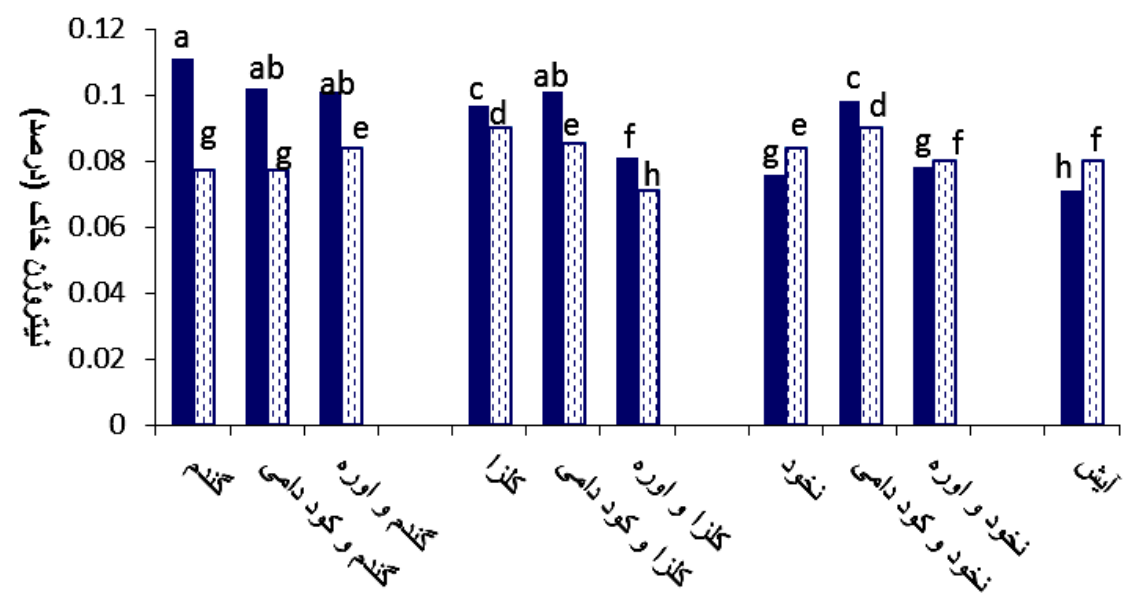

شكل r. تأثير برهمكنش نحوه برگرداندن و مديريت كودى گياهان يوششى بر ميانگين نيتروزن خاك

كياهى تاعمق محدود، اختلاط و آزاد شدن نيتروزن آنها نسـبت

فسفر خاى

براساس نتايج حاصل از تجزيسه واريـانس مقــدار فسـفر خـاك

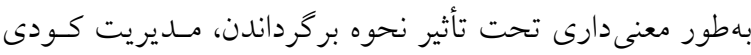

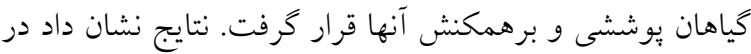
تيمار كم خاكورزى غلظت فسفر خـاك در تيمارهـاى كَاهـان

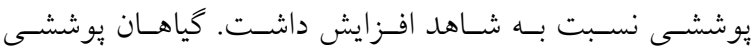
مى تواند فسفر را با افزايش دانهبندى خاك يا با عمل بـهـعنـوان

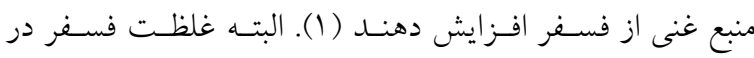

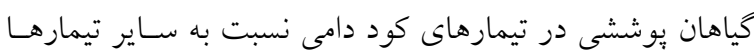

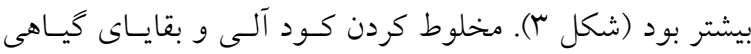

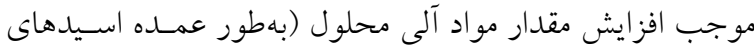

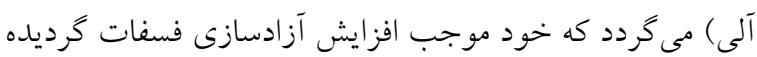

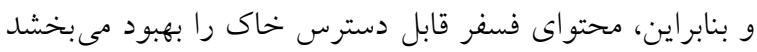

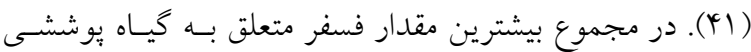

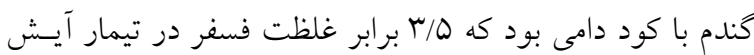

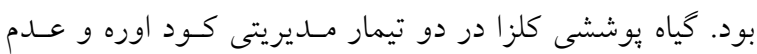

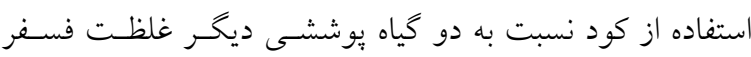

توجه به نياز بالايى كه به نيتروزن دارد به عنوان كَياهـان كيرنسـده

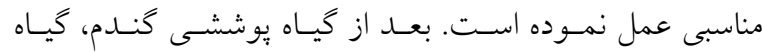

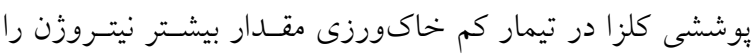

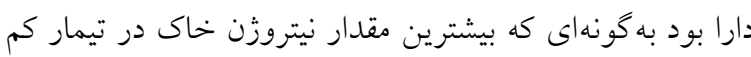

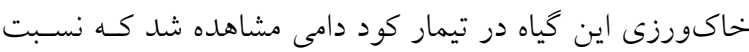

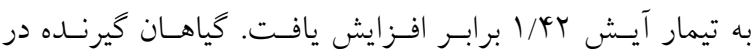
خانواده براسيكا مانند خردل، كلزا و كلم در جذب مقـادير زيـاد

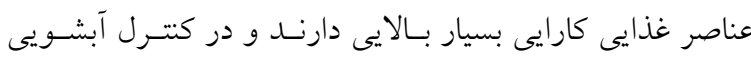

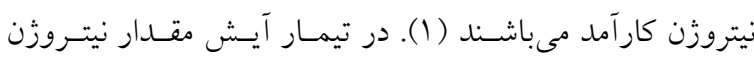

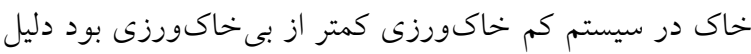

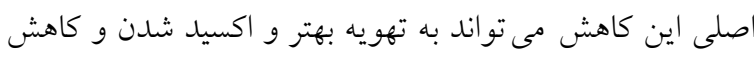

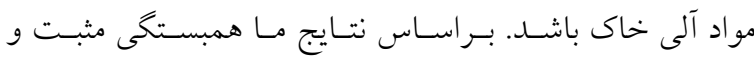

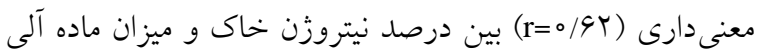

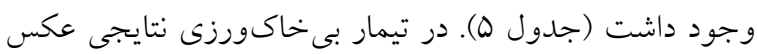

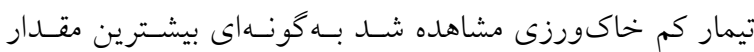
نيتروزن خاك در تيمار كود دامى گياه يوششى نخسود مشـاهده

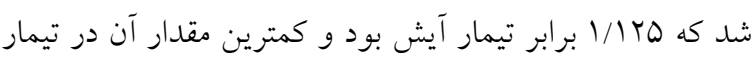

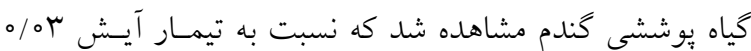
درصــ كمتـر بــود افـزايش مقــدار نيتــروزن در تيمارهـاى كـم خاكورزى را مىتـوان بـهـ بوسـيدكى حجـم زيـادى از بقايـاى 


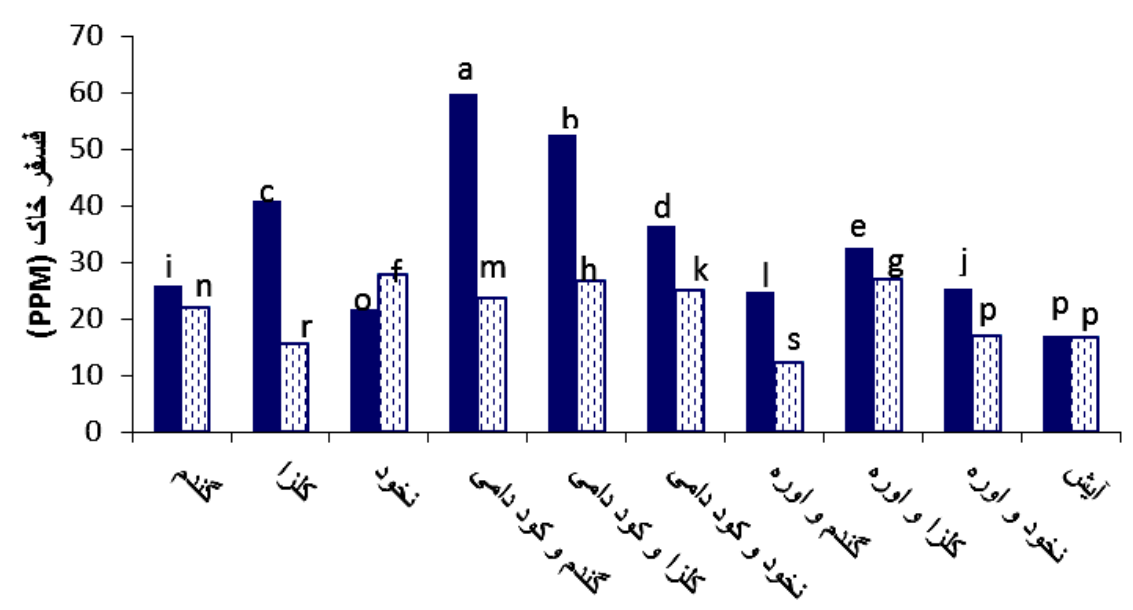

شكل r. تأثير برهمكنش نحوه بر گرداندن و مديريت كودى گياهان يوششى بر ميانخين فسفر خاك (ميلى گرم در كيلوگرم)

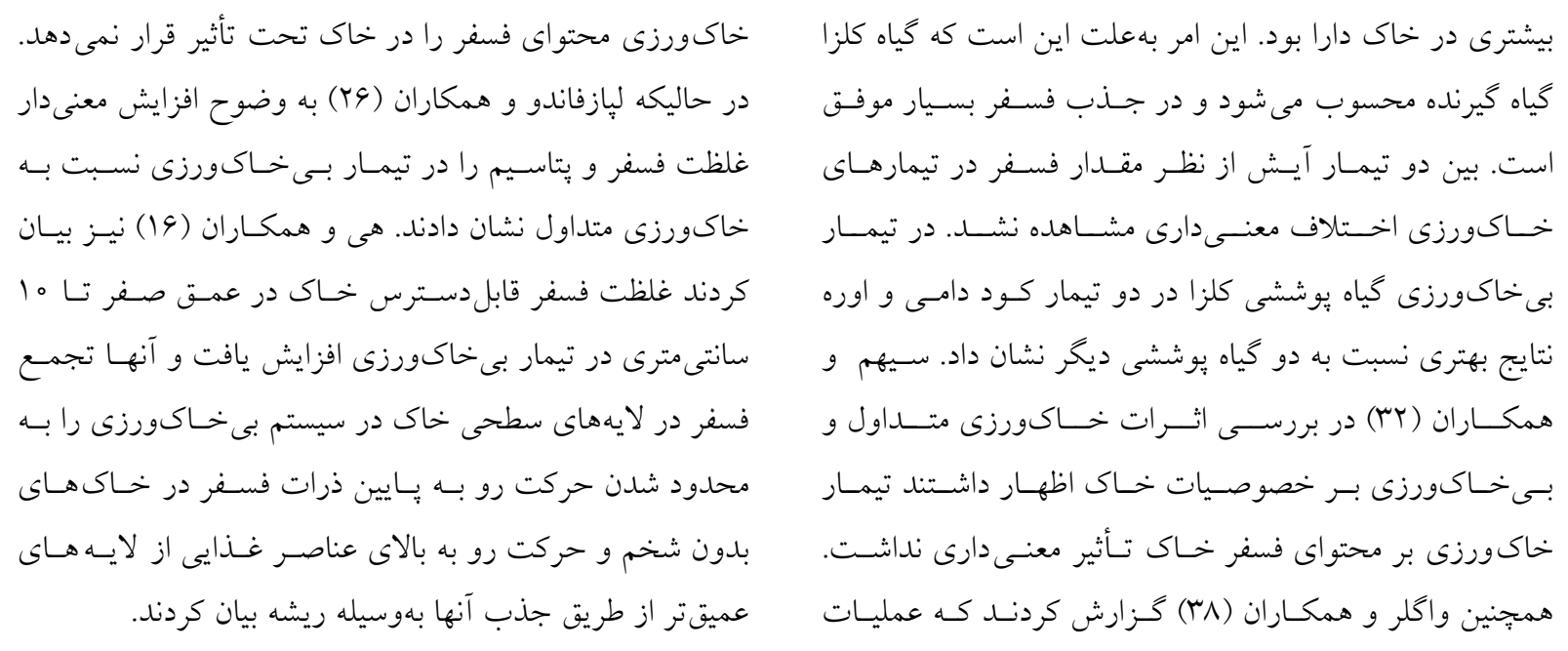

منابع مورد استفاده

ا. سيادت، ع. و م. ر. مرادى تلاوت. •وبا. جنبه هاى كاربردى كشاورزى /ركانيك. انتشارات آموزش و ترويج كشاورزى، تهران.

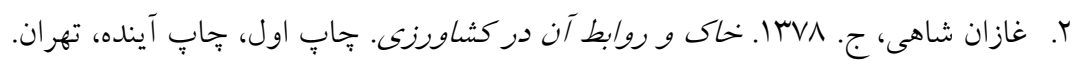

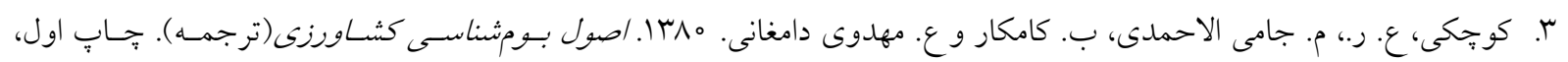
انتشارات جهاد دانشخاهى، مشهد.

4. Ahmad, N., M. Rashid and A. G. Vaes. 1996. Fertilizer and their Use in Pakistan. p. 274. Second Ed., NFDC Pub, No. 4/96, Islamabad.

5. Asagi, N. and H. Ueno. 2009. Nitrogen dynamics in paddy soil applied with various $15 \mathrm{~N}$ labelled green manures. Plant. Soil. 322: 251-262.

6. Bo, Z., Y. Lixia, G. Limei, C. Gong, H. Yuegao, T. Haiming, X. Chunfang, X. Xiaoping, Y. Guangli, N. A. Surya, and Z. Zhaohai. 2012. Performance of two winter cover crops and their impacts on soil properties and two 
subsequent rice crops in Dongting Lake Plain, Hunan, China. Soil. Tillage. Res. 124:95-101.

7. Chen, H. Q., S. Marhan, N. Billen and K. Stahr. 2009. Soil organic carbon and total nitrogen stocks as affected by different land uses in Baden-Wurttemberg, southwest Germany. J. Plant. Nutrition. Soil. Sci. 172: 32-42.

8. Christopher, S. F. and R. Lal. 2007. Nitrogen management affects carbon sequestration in North American cropland soils. Crit. Rev. Plant. Sci. 26: 45-64.

9. Dalal, R. C., D. E. Allen, W. J. Wang, S. Reeves and I. Gibson. 2011. Organic carbon and total nitrogen stocks in a Vertisol following 40 years of no-tillage, crop residue retention and nitrogen fertilization. Soil. Tillage. Res. 112: 133-139.

10. Dean, J. E. and R. R. Weil. 2009. Brassica cover crops for N retention in the Mid-Atlantic coastal plain. J. Environ. Qual. 38: 520-528.

11. Dekker, A. M., A. J. Clark, J. J. Meisinger, F. R. Mulford and M. S. McIntosh. 1994. Legume cover crop contributions to no tillage corn production. Agronomy. J. 86: 126-135.

12. Dinesh, R., M. A. Suryanarayana, S. Ghoshal Chaudhuri and T. E. Sheeja. 2004. Longterm influence of leguminous cover crops on the biochemical properties of a sandy clay loam Fluventic Sulfaquent in a humid tropical region of India. Soil. Tillage. Res. 77: 69-77.

13. Dou, Z., R. H. Fox and J. D. Toth. 1994. Tillage effect on seasonal nitrogen availability in corn supplied with legume green manures. Plant. Soil. 162:203-210.

14. Gabriel, J. L. and M. Quemada. 2011. Replacing bare fallow with cover crops in a maize cropping system: yield, N uptake and fertilizer fate. Euro. J. Agronomy 34:133-143.

15. Gal, A., T. J. Vyn, E. Micheli, E. J. Kladivko and W. W. McFee. 2007. Soil carbon and nitrogen accumulation with long-term no-till versus moldboard plowing overestimated with tilled-zone sampling depths. Soil. Tillage. Res. 96: 42-51.

16. He J., H. Li, G. R. Rabi, Q. Wang, G. Cai, Y. Su, X. Qiao and L. Liu. 2011. Soil properties and crop yields after 11 years of no tillage farming in wheat-maize cropping system in North China Plain. Soil. Tillage. Res. 113: 48-54.

17. Hgh-Jensen, H. and J. K. Schjoerring. 2001. Rhizodeposition of nitrogen by red clover, white clover and ryegrass leys. Soil. Biol. Biochem. 33: 439-448.

18. Hooker, K. V., C. E. Coxon, R. Hackett, L. E. Kirwan, E. O’Keeffe and K. G. Richards. 2008. Evaluation of cover crop and reduced cultivation for reducing nitrate leaching in Ireland. J. Environ. Qual. 37: 138-145.

19. Huang, M., Y. J. Li, J. Z. Wu, M. C. Chen and J. K. Sun. 2006. Effects of subsoiling and mulch tillage on soil properties and grain yield of winter wheat. J. Henan. Uni. Sci. Tech. (Natural Sci.). 2: 74-77 (in Chinese).

20. Iqbal, M., A. U. Hassan, A. Ali and M. Rizwanullah. 2005. Residual effect of tillage and farm manure on some soil physical properties and growth of wheat (Triticum aestivum L.). Int. J. Agri. Biol. 7: 54-57.

21. Jastrow, J. D. 1996. Soil aggregate formation and the accrual of particulate and mineral associated organic matter. Soil. Biol. Biochem. 28: 656-676.

22. Justes, E. B., B. Mary and B. Nicolardot. 1999. Comparing the effectiveness of radish cover crop, oilseed radish volunteers and residue incorporation for nitrate reduction. Nutr. Cycling. .Agroecosyst 55: 207-220.

23. Kennedy, I. R., A. T. M. A. Choudhury, M. L. Kecskes, R. J. Roughley and N. T. Hien. 2004. Non-symbiotic bacterial diazotrophs in crop-farming systems: can their potential for plant growth promotion be better exploited? Soil. Biol. Biochem. 36(8): 1229-1244.

24. Keshavarzpour, F. and M. Rashidi. 2008. Effect of different tillage methods on soil physical properties and crop yield of watermelon (Citrullus vulgaris). World. Appl. Sci. J. 3: 359-364.

25. Khurshid, K., M. Iqbal, M. S. Arif and A. Nawaz. 2006. Effect of tillage and mulch on soil physical properties and growth of maize. Int. J. Agri. Biol. 8: 593-596.

26. Lopez-Fando C., J. Dorado and M. T. Pardo. 2007. Effects of zone-tillage in rotation with no-tillage on soil properties and crop yields in a semi-arid soil from central Spain. Soil. Tillage. Res. 95: 266-276.

27. Moller K. and H. J. Reents. 2009. Effects of various cover crops after peas on nitrate leaching and nitrogen supply to succeeding winter wheat or potato crops. J. Plant .Nutr. Soil. Sci. 172: 277-287.

28. Ogban, P. I., W. N. Ogunewe, R. I. Dike, A. C. Ajaelo, N. I. Ikeata, U. E. Achumba and E. E. Nyong. 2008. Effect of tillage and mulching practices on soil properties and growth and yield of cowpea (Vigna unguiculata (L), WALP) in Southeastern Nigeria. J. Tropical. Agri. Food. Environ. Extension 7(2): 118-128.

29. Roe, N. E., J. Stofella and D. Ggreatz. 1997. Compost from various municipal solid wastes feed stocks affect vegetable crops, II Growth, yield and fruit quality. J. ASHS. 122: 433-437.

30. Sainju, U. M., H. H. Schomberg, B. P. Singh, W. F. Whitehead, P. G. Tillman and S. L. Lachnicht-Weyers. 2007. Cover crop effect on soil carbon fractions under conservation tillage cotton. Soil. Tillage. Res. 96: 205-218.

31. Sanchez, J. E., T. C. Willson, K. Kizilkaya, E. Parker and R. R. Harwood. 2001. Enhancing the mineralizable N pool through substrate diversity in long term cropping systems. Soil. Sci. Soc. America. J. 65: 1442-1447.

Sihem, B. M. M., E. Faık, B. H. Moncef and N. Saıd. 2010. Comparative effects of conventional and no-tillage 
management on some soil properties under Mediterranean semi-arid conditions in northwestern Tunisia. Soil. Tillage. Res. 106: 247-253.

33. Six, J., E. T. Elliott and K. Paustian. 1999. Aggregate and soil organic matter dynamics under conventional and notillage systems. Soil. Sci. Soc. America. J. 63: 1350-1358.

34. Snapp, S. S. and S. N. Silim. 2002. Farmer preferences and legume intensification for low nutrient environments. Plant. Soil. 245: 181-192.

35. Snapp, S. S., S. M. Swinton, R. Labart, D. Mutch, J. R. Black, R. Leep, J. Nyiraneza and K. O’Neil. 2005. Evaluating cover crops for benefits, costs and performance within cropping system niches. Agronomy J. 97: 322332.

36. Steenwerth, K. and K. M. Belina. 2008. Cover crops and cultivation: impacts on soil N dynamics and microbiological function in a Mediterranean vineyard agroecosystem. Appl. Soil Ecol. 40: 370-380.

37. Stute, J. K. and J. L. Posner. 1995. Legume cover crops as a nitrogen source for corn in an oat-corn rotation. J. Prod. Agri. 8: 385-390.

38. Vogeler, I., J. Rogasik, U. Funder, K. Panten and E. Schnug. 2009. Effect of tillage systems and P-fertilization on soil physical and chemical properties, crop yield and nutrient uptake. Soil. Tillage. Res. 103: 137-143.

39. Zhang, W., L. B. Hou, B. Zhang, J. Wen, G. J. Wang, W. C. Jiang and Y. Jia. 2006. Effects of different cultivation ways on soil physical capability in western semi-arid area of Liaoning Province. J. Arid. Land. Resource Environ. 3: 149-153 (in Chinese).

40. Zhang, X. R., H. W. Li, J. He, Q. J. Wang and M. H. Golabi. 2009. Influence of conservation tillage practices on soil properties and crop yields for maize and wheat cultivation in Beijing, China. Aust. J. Soil. Res. 47: 362-371.

41. Zsolony, A. and G. Gorlita. 1994. Water extractable organic matter in arable soils: effects of drought and long term fertilization. Soil. Biology. Biochem. 26: 1257-1261. 


\title{
Effects of Green Manure Management and Fertilization Treatments on the Chemical and Physical Properties and Fertility of Soil
}

\author{
M. Shamsaddin saied ${ }^{1 *}$ A. Ghanbari², M. Ramroudi ${ }^{2}$ and A. Khezri ${ }^{3}$
}

(Received: May 30-2014 ; Accepted: June 11-2016)

\begin{abstract}
Cover crops, conservation tillage systems and organic fertilizers have played an important role in maintaining or enhancing soil quality. In order to assess the combined effects of these techniques on soil quality an experiment was conducted as split Plot experiment based on randomized complete block design with three replications at Shahid Bahonar University of Kerman in 2011-2012.

The method of return of cover crops to soil included reduced tillage (disc) and no-till (herbicide glyphosate + cutting) as the main factor and manure application management included cover crops (wheat, canola and peas) without the use of urea, cover crops with a consumption of $25 \mathrm{t} / \mathrm{ha}$ of manure, Cover crop with $75 \mathrm{~kg}$ of urea and fallow treatments (without cover crop) as subplots. The results showed that the highest concentration of nutrients (except $\mathrm{N}$ and $\mathrm{P}$ concentrations in the plant), the nutrient yield and biomass of cover crops belonged to wheat treated with urea fertilizer. Soil properties such as bulk density, $\mathrm{pH}$, organic matter and soil nutrient concentrations (nitrogen, phosphorus and potassium) were significantly affected by fertilizer management and the method of return of cover crops to soil (except $\mathrm{pH}$ ) and soil organic matter content and nutrient concentration were affected by their interactions. In wheat cover crop treatments with urea with \%27.53 reduction in bulk density, \%20.88 increase in the porosity, organic matter 2.4 times and nitrogen 1.5 times compared to the fallow treatment was the best treatment that wasn't significantly different from the wheat treated with manure in low- tillage system. Wheat treated by manure had the highest phosphorus that was 3.5 times of the phosphorus concentration in the fallow treatment. So, in order to develop sustainable agriculture, reducing the use of synthetic fertilizers and environmental protection, the wheat cover crop treatments with manure and low- tillage cropping systems would be appropriate in Kerman.
\end{abstract}

Keywords: cover crops, fertilizer management, method of return, soil quality

1. Dept. of Plant Production, Faculty of Agric. Univ. of Kerman, Bardsir, Kerman, Iran.

2. Dept. of Agronomy and Plant Breeding, Faculty of Agric. Univ. of Zabol, Zabol, Iran.

3. Dept. of Animal Sci. Faculty of Agric. Univ. of Kerman, Kerman, Iran.

*: Corresponding Author, Email: mohadeseh_said@yahoo.com 